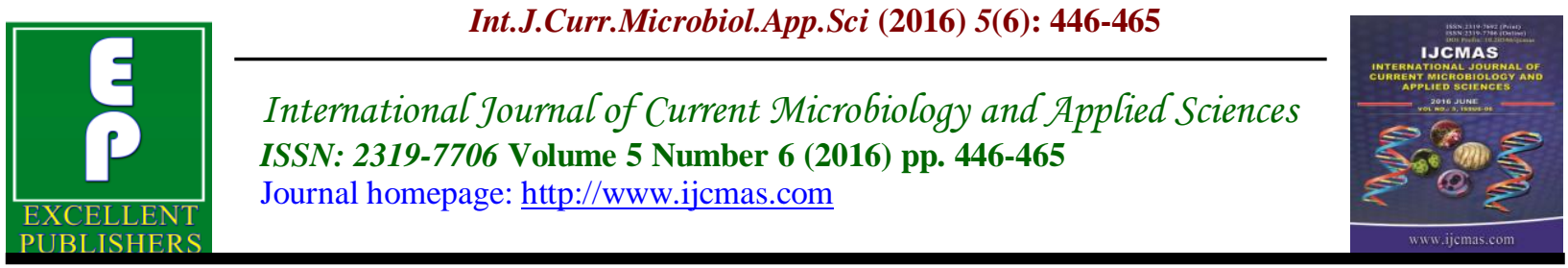

Review Article

http://dx.doi.org/10.20546/ijcmas.2016.506.052

\title{
Tinospora cordifolia with Reference to Biological and Microbial Properties
}

\author{
S.K. Dwivedi and Enespa* \\ Department of Environmental Science, Babasaheb Bhimrao Ambedkar (A Central) University, \\ Lucknow-226025, U. P. India \\ *Corresponding author
}

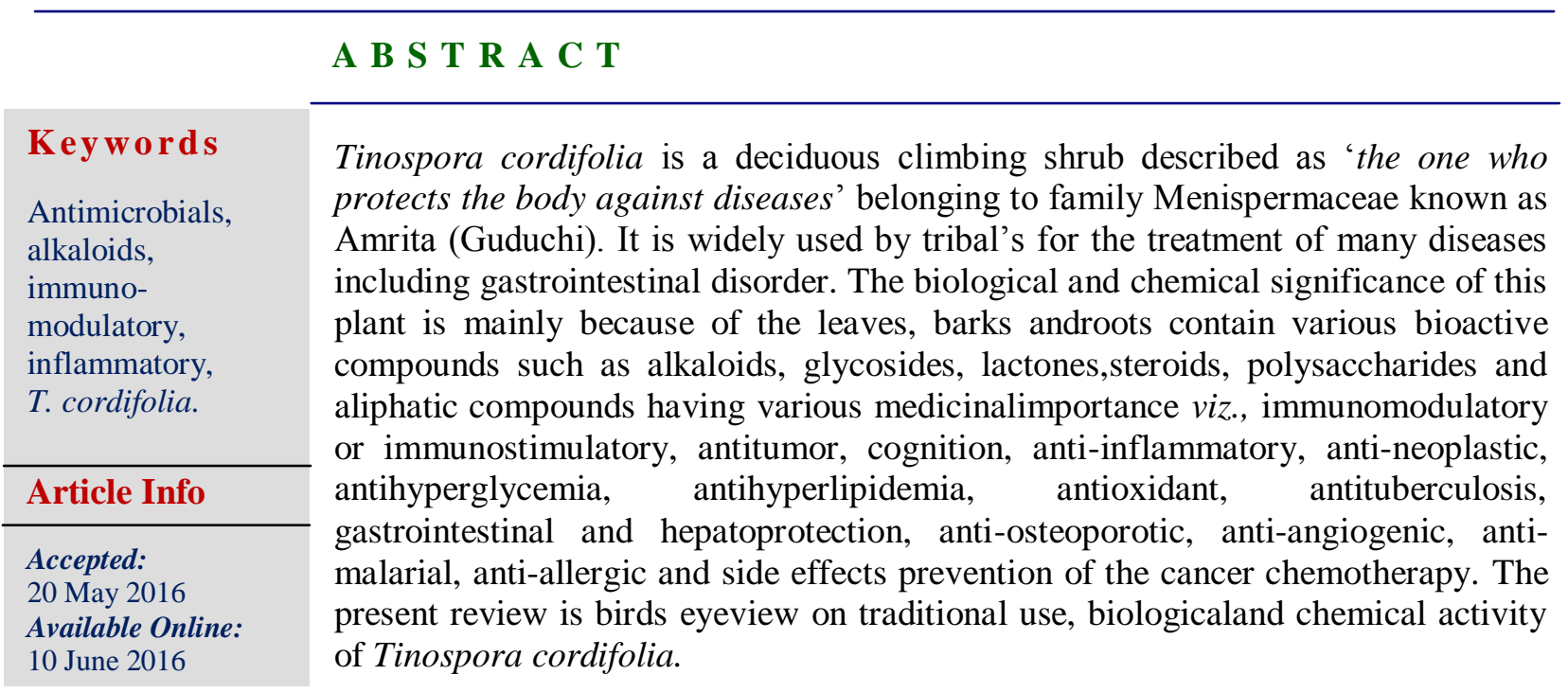

\section{Introduction}

India is well known historically as a land of herbs, shrub, spices and aromatic plants and continues to be one of the leading producers of medicinal plants in the world (Prajapati et al., 2005).Medicinal plants since times immemorial have been used as a source of medicine (Shukla and Gardner, 2006). The widespread use of herbal remedies and healthcare preparations as those described in ancient texts such as the Vedas and the Bible and obtained from commonly used traditional shrub and medicinal plants have been traced to the occurrence of natural products with medicinal properties (Talbot et al., 2006).
Tinospora cordifolia (Willd.) Miers exHook. F. and Thoms (Menispermaceae) (Upadhyay et al., 2010) is an important shrub in folk and Ayurvedic system of medicine found throughout India, especially tropical part of India and Karnataka (Shivakumar and Krishnamurthy, 2002) followed by China. It is described as 'the one who protects the body against disease'. It is also called as marginal shrub due to its property of curing a lot of diseases in modern system of medicine (Srivastava, 2011). It contains therapeutic strength, detoxifying and cleansing the whole system, specifically via liver. It is widely used as anti-bacterial 
(Dorman and Deans, 2000)), antifungal (Dwivedi and Enespa, 2012) analgesic (Bousquet et al., 1994), antipyretic (Ikram et $a l .$, 1987) and also for the treatment of jaundice, skin diseases, anemia etc. The stem is used in dyspepsia, debility and urinary diseases (Ahmad et al., 2009). Fever and urinary diseases (Bishayi et al., 2002). The biter principle present shows several medicinal applications viz., antiperiodic, antispasmodic, antiinflammatory, immunomodulatory or immunostimulatory, antitumor, cognition, antineoplastic, antihyperglycemia, antihyperlipidemia, antioxidant, antituberculosis, gastrointestinal and hepatoprotection, anti-osteoporotic, antiangiogenic, anti-malarial, anti-allergic and antipyretic properties (Stanely et al., 2000; Rathi et al., 2002; Bishayi et al., 2002; Stanely and Menon, 2003; Rawal et al., 2004; Singh et al., 2004, 2005; Purandare, 2007; Wang et al., 2010). The root is a powerful emetic and used for visceral obstructions, stem extract as antioxidant while its water extract is used in leprosy and antidiabetic cases. It's raising the efficiency of protective white blood cells and builds up our immune system so thatsome of the health experts prescribe $T$. cordifolia for some sexually transmitted diseases such asgonorrhea (Raghu et al., 2009). The water, ethanol/methanol, methylene chloride extracts of $T$. cordifolia have been evaluated for antineoplastic effects. Tumor mass reduction and increased survival time have been observed with administration of the extract in mice with induced carcinomas (Leyon and Kuttan, 2004; Jagetia and Rao, 2006). At low doses, an ethanol extract of $T$. cordifolia increased bone marrow cell counts, while higher doses resulted in decreased counts in mice with induced lymphoma (Singhet al., 2006).T. cordifolia induces proliferation and myeloid differentiation of bone marrow precursor cells in a tumor-bearing host (Singh et al.,
2005), activates tumor-associated macrophages-derived dendritic cells (Singh et al., 2005) was effective against various cancers (Mittal and Singh, 2009), killing the cancer cells very effectively in vitro (Jagetia and Rao, 2006), inhibits skin carcinogenesis in mice(Chaudhary et al., 2008) and inhibits experimental metastasis (Leyon and Kuttan, 2004). T. cordifolia may offer an alternative treatmentstrategy for cancer in combination with gamma radiation (Rao et al., 2005;Goel et al., 2004).

The pharmaceutical significance of this shrub is mainly because of various bioactive compounds found in this plant such as glucoside, alkaloidal constituents including berberine, three fatty alcohol, a bitter glucoside giloin, a non-glucosidic bitter substance gilonin (Singh et al., 2003).

\section{Occurrence and Botanical Description of Tinospora cordifolia}

Tinospora cordifolia indigenous to India, China, Myanmar, Sri Lanka, Thailand, Philippines, Indonesia, Malaysia, Borneo, Vietnam, Bangladesh, North Africa, West Africa, and South Africa (Pendse et al., 1981;Singh et al., 2003; Mia et al., 2009; Jain et al., 2010)and also contains about 70 genera and 450 species. It typically grows in deciduous and dry forests at elevations up to $1000 \mathrm{ft}$.

T. cordifolia is a climbing shrub native to lower elevation in tropical areas of the Indian subcontinent and climbs numerous types of trees (Premila, 2006). It prefers wide range of soil, acid to alkaline and needs moderate level of soil moisture(Sharma et al., 2010c).

It is also known as Gilo (Arabic); Amarlata (Assamese); Gadancha, Guluncha, Giloe (Bengali); K'uan chu Hsing (Chinese); 
Culancha (French); Tinospora (English); Gado, Galo, Gulo (Gujerati); Giloe, Gulbel, Gurcha (Hindi); Amrytu, Sittamrytu (Malayalam); Ambarvel, Giroli, Gulvel (Marathi), Garjo (Nepali); Gulancha (Oriya); Gulbel (Persian); Gilo (Punjabi, Kashmiri), Amrita, Guduchi, (Sanskrit); Gurjo (Sikkikim); Amridavalli, Niraidarudian (Tamil); Guduchi, Iruluchi (Telugu) and Guruch (Urdu) (Kirtikar and Basu, 1918; Anon, 1956; The Ayurvedic Pharmacopoeia of India, 2001).

Tinospora cordifolia is a deciduous plant that grows to 1.0 meters (3.3feet) high by 0.5 meters (1.65 feet). Stem of T. cordifolia are succulent and having long filliform fleshy aerial roots which arise from the branches. Bark is thin, greyish or creamy white in colour, when peeled fleshy stem is exposed. It often attains a great height and mostly climbs up the trunks of large neem trees. Leaves of $T$. cordifolia are heart shaped, membranous, juicy and cordate. $T$. cordifolia has greenish flowers, which are unisexual (Hooker, 1875; Kirtikar and Basu, 1918) and bloom in summer. Male flower are small, yellow or green coloured occur in clusters whereas Female flower occur singly. Fruits are Pea shaped, fleshy, shiny turn red when boiled and occur in winter. Seeds of $T$. cordifolia are curved and pea size.

\section{Constituents of Tinospora cordifolia}

T. cordifolia contains high fibre (15.9\%), sufficient protein (4.5\%-11.2\%), carbohydrate (61.66\%), and low fat (3.1\%). Its nutritive value is 292.54 calories per 100 g. It has high potassium $(0.845 \%)$, high chromium $(0.006 \%)$, sufficient iron $(0.28 \%)$ and calcium $(0.131 \%)$, important in various regulatory functions (Nile and Khobragade, 2009).
The chemical constituents present in $T$. cordifolia belonging to different classes such as alkaloids, diterpenoid lactones, glycosides, steroids, sesquiterpenoid, phenolics, aliphatic compounds and polysaccharides. Three major groups of compounds; protoberberine alkaloids, terpenoids and polysaccharides are considered as putative active constituents of T. cordifolia (Chintalwaret al., 1999; Bisset and Nwaiwu, 1983). These chemical constituents in different parts of plant and their role in various therapeutic actions have been presented in Table 1 and 2 .

\section{Therapeutic and Biological Activities}

Tinospora cordifolia, known as guduchi, is a plant prescribed in Ayurveda, the Indian traditional system of Medicine as a Rasayana (Thatte and Dhanukar, 1986). Guduchi is a promising drug entity which should enter the world market by evidencebased research for therapeutics (Jagetia and Rao 2006).It is successfully used to cure many diseases. Some medicinal properties of $T$. cordifolia in disease control are as followes:

\section{Anti-cancer/ Antitumor Activity}

Extracts of Tinospora cordifolia (TCE) have been shown to possess anti-tumor properties. According to Jagetia and Rao (2006) the decline in the clonogenicity, glutathione-Stransferase (GST) activity, increase in lipid peroxidation with a peak at $4 \mathrm{~h}$ and lactate dehydrogenase (LDH) release with a peak at $2 \mathrm{hHeLa}$ cells, were exposed to various concentrations of TCE. Alcoholic extract of $T$. cordifolia has been reported to be cytotoxic in a transplantable mouse tumor. Increased lipid peroxidation, LDH(decline in surviving fraction) release accompanied by a decline in GST concentration by guduchi is some of the important events 
leading to cell death. Lipidperoxidation is an important event related to cell death and has been reported to cause severe impairment of membrane function through increased membrane permeability and membrane protein oxidation and eventually cell death by damaging the cellular DNA. Administration of the polysaccharide fraction from Tinospora cordifolia was found to be very effective in reducing the metastatic potential of melanoma cells, inhibition in the metastases formation in the lungs of syngeneic mice, when the drug was administered simultaneously with tumour challenge. Biochemical parameters such as lung collagen hydroxyproline, hexosamines and uronic acids that are markers of neoplastic development were reduced significantly in the treated animals (Jagetia and Rao, 2006).

\section{Anti-diabetic and Hyperglycaemic activity}

Tinospora cordifolia is widely used for treating the diabetes mellitus. According to Stanely et al.(2000) the aqueous $T$. cordifolia root extract (TCREt) to alloxan diabetic rats caused a significant reduction in blood glucose and brain lipids. The extract caused an increase in body weight, total haemoglobin and hepatic hexokinase. The root extract also lowers hepatic glucose -6-phosphatase and serum acid phosphatase, alkaline phosphatase and lactate dehydrogenase in diabetic rats thus TCREt has hypoglycaemic and hypolipidaemic effect (Stanely et al., 2000). The extract also prevented a decrease in body weight (Stanely and Menon, 2001).

The aqueous, alcoholic and chloroform extracts of the leaves of $T$. cordifolia in doses of 50, 100 and $200 \mathrm{mg} / \mathrm{kg}$ body weight to normal and alloxan-diabetic induced rabbits exerted significant hypohlycaemic effect (Wadood et al., 1992).
An Ayurvedic compound formulation Transina (TR) containing $T$. cordifolia and other drugs was studied for hyperglycaemia and superoxide dismutase (SOD) activity of pancreatic islet cells. The result indicates that the earlier reported antihyperglycaemia activity of streptozotocin (STZ) being the consequence of decrease in islet SOD activity leading to the accumulation of degenerative oxidative free radicals in islet beta cells (Bhattacharya et al., 1997).

\section{Anti-inflammatory Activity}

Anti-inflammatory potency of water extract of $T$. cordifolia has been proved by the study on induced oedema arthritis and on human arthritis. The dried of $T$. cordifolia produced significant anti-inflammatory effect in both acute and sub-acute models of inflammation. T. cordifolia was found to be more effective than acetylsalicylic acid in acute inflammation (Jana et al., 1999). The aqueous stem extract of $T$. cordifolia has been antagonize the various autocoids in the pathophysiology of clinical joint inflammation.

\section{Antioxidant Activity}

The alcoholic root extract of $T$. cordifolia has antioxidant defence mechanism in alloxan induced diabetic rats and also significant increase in the concentration of thiobarbituric acid reactive substances in liver and kidney. The decreased concentration of glutathione (GSH), activity of superoxide dismutase (SOD) and catalase in liver and kidney of diabetic rats (Prince $e t$ al., 2004). Methew and Kuttan (1997) reported the antioxidant activity and amelioration of cyclophosphamide-induced toxicity. The direct and indirect antioxidant actions of $T$. cordifolia probably act in corroboration to manifest the overall radioprotective effect (Goel et al., 2002). 


\section{Anti-stress Activity}

Ethanol extract of $T$. cordifolia at the dose of $100 \mathrm{mg} / \mathrm{kg}$ exhibited significant antistress activity compared with diazepam at the dose of $2.5 \mathrm{mg} / \mathrm{kg}$ (Sarma et al., 1996).

\section{Anti-ulcer Activity}

The ethanol root extract of $T$. cordifolia was observed to induce a marked protective action against restrain stress induced ulcerization comparable to that of diazepam (Sarma et al., 1995).

\section{Digestive Activity}

The antiamoebic effect of a crude drug formulation containing $T$. cordifolia against Entamoeba histolytica was studied. According to Sohni et al. (1995) reported varying degrees in inhibition of the enzymes, viz., DNase, RNase, acid phosphatase, alkaline phosphatase and protease activities of crude extracts of axenically cultured amoebae.

\section{Hypolipidaemic Activity}

The aqueous extract of Tinospora cordifolia roots has hypolipidaemic properties. The extract of $T$. cordifolia roots $(2.5$ and $5.0 \mathrm{~g}$ : $\mathrm{kg}$ body weight) for 6 weeks resulted in a significant reduction in serum, tissue cholesterol, phospholipids and free fatty acids in alloxan diabetic rats. The effect of T. cordifolia roots at 2.5 and $5.0 \mathrm{~g} / \mathrm{kg}$ body weight was better than glibenclamide. Insulin restored all the parameters to near normal values and it was observed that a level of serum lipids in alloxan diabetic rats was higher. The level of serum lipids was usually raised in diabetes and such an elevation represents a risk factor for coronary heart disease (Shamaony et al., 1994). Lowering of serum lipids levels through dietary or drugs therapy seems to be associated with a decrease in the risk of vascular disease (Rhoads et al., 1976). The abnormal high concentration of serum lipids in diabetes is mainly due to the increase in the mobilization of free fatty acids from the peripheral depots, since insulin inhibits the hormone sensitive lipase. On the other hand, glucagon, catecholamines and other hormones enhance lipolysis.

The marked hyperlipemia that characterizes the diabetic state may therefore be regarded as a consequence of the uninhibited actions of lipolytic hormones on the fat depots (Shamaony et al., 1994). According to Kumar and Menon (1992) the levels of cholesterol, phospholipids and free fatty acids in liver, kidney and heart in alloxan diabetic rats was higher.

\section{Immuno-modulatory Activity}

T. cordifoliais used to improve the immune system and the body resistance against infections. The alcoholic and aqueous extracts of $T$. cordifolia have been tested successfully for immuno-modulatory activity. Pretreatment with $T$. cordifolia reduced mortality in mice injected with $E$. coli intraperitoneally. This was associated with significantly improved bacterial clearance as well as improved phagocytic and intracellular bactericidal capacities of neutrophils in the $T$. cordifolia treated group. According to Desai et al. (2002) the dry stem crude extract (DSCE) of $T$. cordifolia contained a polyclonal B cell mitogen, G1-4Awhich enhance the immune response in mice.

Treatment of $T$. cordifolia extract also deleted the immunosuppressive effect of $\mathrm{CCl}_{4}$.There was significant increment in the functional capacities of rat peritoneal macrophages. Treatment by $T$. cordifolia 
extract may be the critical remedy for the adverse effect of $\mathrm{CCl}_{4}$ in liver function as well as immune functions (Bishayi et al., 2002). In clinical study, it has afforded protection in cholestatic patients against $E$. coli infection (Dhuby, 1997). The water extract of T. cordifolia was found to be more potent than other extract (Manjreker et al., 2000). According to Atal et al. (1986) $T$. cordifolia improves the phagocytic function without effecting the humoral or cell mediated immune system.

\section{Hepatoprotective Activity}

Effect of $T$. cordifolia extract on modulation of hepatic functions is also reported. Treatment with $T$. cordifolia extracts (100 $\mathrm{mg} / \mathrm{kg}$ body weight for 15 days) in $\mathrm{CCl}_{4}$ intoxicated rat it was found that liver was protected (Bishayi et al., 2002). According to Reddy et al. (1993) the chloroform extract of $T$. cordifolia failed to reduce the liver toxicity in tested dose $(200 \mathrm{mg} / \mathrm{kg})$. The extract of $T$. cordifolia had also exhibited in vitro inactivating property against Hepatitis $B$ and $E$ surface antigen in 48-72 hrs (Mehrotra et al., 2000).

\section{Cognition (Learning and Memory) Activity/ Mental disorders}

Dementia is a syndrome of failing memoryand other intellectual functions with little or no disturbance in consciousness (Ropper et al., 2009).Degeneration of the cerebral neurons is oneof the commonest and vital causes fordementia with increasing age, thereby leading to deterioration in quality of life in elderly. T. cordifolia (TC) extract effects on learning and memory in normal and cyclosporine induced memory deficit rats and also used as mental disorders (Kulkami and Verma, 1993).

\section{Antimicrobial Properties}

Herbal medicine represents one of the most important fields of traditional medicine all over the world. To promote the proper use of herbal medicine and to determine their potential as sources for new drugs, it is essential to study medicinal plants. Contrary to the synthetic drugs, antimicrobials of plant origin are not associated with side effects and have an enormous therapeutic potential to heal many infectious diseases. Plant-based antimicrobials have enormous therapeutic potential as they can serve the purpose with lesser side effects that are often associated with synthetic antimicrobials (Iwu et al., 1999). Thousands of secondary plant products have been identified and it is estimated that thousands of these compounds still exist. Since secondary metabolites from natural resources have been elaborated within living systems, they are often perceived as showing more "drug - likeness and biological friendliness than totally synthetic molecules" making them good candidates for further drug development (Koehn and Carter, 2005; Balunas and Kinghorn, 2005; Drahl et al., 2005) .

In recent years the use of eco-friendly technologies especially use of plant extracts are gaining tremendous importance for the control of plant disease in agriculture because they are less harmful to the human health and environment (Duru et al., 2003), and also these are considered as potential alternatives to chemical agents which are hazardous to human and animal health (Mukhopadhyay, 1996).

The activity of plant extracts on bacteria and fungi has been studied by a very large number of researchers in different parts of the world (Vuuren and Naidoo, 2010; Bhengraj et al., 2008).Human infections, particularly skin and mucosal surfaces, constitute a serious problem, especially in tropical and subtropical developing countries (Portillo et al., 2001). In humans, 
fungal infections range from superficial to deeply invasive or disseminated, and have increased dramatically in recent years. The treatment of mycoses has lagged behind bacterial chemotherapy and fewer antifungal than antibacterial substances are available. Therefore, a search for new antifungal drugs is extremely necessary (Fortes et al., 2008).

Infectious diseases, particularly skin and mucosal infections, are common in most of the tribal inhabitants due to lack of sanitation, potable water and awareness of hygienic food habits. An important group of these skin pathogens are the fungi, among which dermatophytes and Candida spp. are prominent (Fan et al., 2008; Toledo et al., 2011). Antimicrobial properties of certain Indian medicinal plants were reported based on folklore information (Gupta and Banerjee, 2008; Tharkar et al., 2010; Duraipandiyan et al., 2010), and a few attempts were made on inhibitory activity against certain pathogenic bacteria and fungi.

T. cordifolia has been shown to possess antiallergic (Badar et al., 2005), anti-diabetic (Prince et al., 1998), anti-hepatotoxic (Bishayi et al., 2002), anti-pyretic (Bafna et $a l ., 2005)$ and anti-inflammatory properties (Purandare et al., 2007). This activity can be attributed to tinocordifolin (Maurya and Handa, 1998); sesquiterpene glucoside, tinocordifolioside (Maurya et al., 1997); cordifoliside D and cordifoliside (Gangan et al., 1995); tinosponone and tinocordioside, clerodane (Maurya et al., 1995); cordioside (1995).

The Tinospora cordifolia extract have been used to possess desirable bioactivities including fungicidal activities (Soliman and Badeaa, 2000), bactericidal (Dorman and Deans, 2000; Aher and Wahi, 2010), insecticidal (Isman, 2000) and nematocidal (Pandey et al., 2000) activities. The antifungal activity of Tinospora cordifolia leaf extract against Fusarium oxysporum f.sp. lycopersici and Fusarium solani causing tomato and brinjal wilt have been studied at three concentrations viz., 25, 50, $75 \%$ (v/v) in vitro by poisoned food technique and recorded $100 \%$ resultagainst both the pathogenic Fusarium at $75 \%$ concentration (Dwivedi and Enespa, 2012). Singh et al. ( 2010) reported the antifungal activity of methanolic crude extract of Acorus calamus, Tinospora cordifolia and Celestrus paniculatus against Alternaria solani, Curvularia lunata, Fusarium sp., Bipolaris sp. and Helminthosporium sp. at different concentrations (1000, 2000, 3000, 4000 and $5000 \mu \mathrm{g} / \mathrm{ml})$. At $5000 \mu \mathrm{g} / \mathrm{ml}$ crude extract of Tinospora cordifolia was found to be highly effective against Helminthosporium sp. followed by Acorus calamus against Alternaria solani. On the other hand at $5000 \mathrm{ug} / \mathrm{ml}$, Celestrus paniculatus showed better activity against Alternaria solani and Helminthosporium followed by Acorus calamus against Alternaria solani at $4000 \mathrm{ug} / \mathrm{ml}$. At 5000 $\mathrm{ug} / \mathrm{ml}$, all the three crude extracts showed least activity against the fungus Curvularia lunata and Fusarium sp. except Acorus calamus that showed better activity against Curvularia lunata.

Duraipandiyan and Ignacimuthu (2011) reported that the antifungal activity of hexane, ethyl acetate and methanol extracts of Albizzia procera, Asclepias curassavica, Atalantia monophylla, Azima tetracantha, Cassia fistula, Cinnomomum verum, Costus specious, Nymphaea stellata, Osbeckia chinensis, Piper argyrophyllum, Punica granatum, Tinospora cordifolia and Toddalia asiatica against human pathogenic fungi viz. Trichophyton rubrum MTCC 296,T. rubrum57/01, Trichophyton mentagrophytes66/01, Trichophyton simii 110/02, Epidermophyton floccosum 73/01, 
Scopulariopsis sp. 101/01 Aspergillus niger MTCC 1344, Botrytis cinerea, Curvularia lunata 46/01, Magnaporthegrisea and Candida albicans MTCC227. The ethyl acetate extracts inhibited large number of fungal growth and hexane also nearly showed the same level of inhibition against fungal growth while the methanol extracts showed the minimum antifungal activity. The promising antifungal activity observed in A. procera, C. Speciosus, C. Fistula and T. asiatica.

Bansal et al. (2012) reported that the antimicrobial effect of different extracts of Tinospora cordifolia against four pathogenic bacteria (Escherichia coli, Staphylococcus aureus, Streptococcus mutans and Pseudomonas aeruginosa) and one fungus (Candida albicans). The efficacy of extracts was measured in terms of zone of inhibition (mm). Butanol extract was the most effective against all the tested microbes as compared to the other tested extracts. The decoction and toluene was ineffective against all the microbes except $E$. coli where benzene was ineffective. The phytochemical screening of various extracts revealed the presence of tannins, steroids, flavonoids, cardiac glycosides and saponnins. These results suggested that butanol extract is not only the important source of antimicrobial component but can also be used for developing novel antimicrobial biorationals of plant origin.

Mahesh and Satish (2008) reported that antimicrobial activity of methanol leaf and bark extracts of Tinospora cordifolia against bacterial strains viz. Bacillus subtilis, Escherichia coli, Pseudomonas fluorescens, Staphylococcus aureus and Xanthomonas axonopodis pv. Malvacearum and fungal strains viz. Aspergillus flavus, Dreschlera turcica and Fusarium verticillioides. $T$. cordifolia leaf extracts showed almost similar zone of inhibition against all the tested bacteria except Xanthomonas axonopodis pv. Malvacearum, which showed highest antibacterial activity (17 $\mathrm{mm})$. The bark extract of $T$. cordifolia showed varied in the zone of inhibition from 10-14 mm against all the tested bacteria. The T. cordifolialeaf extract recorded better (14 $\mathrm{mm}$ ) zone of inhibition (antifungal activity) against $D$. turcica followed by bark extract (13mm).

The antifungal activity and minimum inhibitory concentration (MIC) of Valeriana jatamansi (Sugandhbala), Coleus barbatus (Pathar choor), Berberis aristata (Kingore), Asparagus racemosus (Satrawal), Andrographis paniculata (Kalmegha), Achyranthes aspera (Latjiri), Tinospora cordifolia (Giloei), Plantago depressa (Isabgol) plant extracts against Aspergillus niger and Candida albicans at different solvents such as hydro-alcohol (50\% v/v) and hexane as medicines. Hydro-alcoholic extracts of all the plants showed maximum antifungal activity in comparison to hexane extracts. Hydroalcoholic extracts of Andrographis paniculata and Achyranthes aspera showed maximum potency against Aspergillus niger and Candida albicans at highest MIC value of 0.5 and $0.3 \mathrm{mg} / \mathrm{ml}$ respectively. Hexane extracts of Andrographis paniculata showed highest MIC value of $0.7 \mathrm{mg} / \mathrm{ml}$ against Aspergillus niger (Mathur et al., 2011). However the antibacterial activity of aqueous and methanolic (fruit and stem) extracts of Tinospora cordifolia was tested against four human pathogenic bacteria namely Bacillus cereus, Bacillus fusiformis, Escherichia coli and Klebsiella pneumonia by using paper disc agar diffusion method. All extracts of stem and fruit exhibited significant antibacterial activity against the tested bacteria. However, the strongest antibacterial activity was observed in 
methanol fruit extract of Tinospora cordifolia against Klebsiella pneumoniae with maximum inhibition zone (22 mm). The aqueous fruit extract showed minimum antibacterial activity against Bacillus cereus with $(10 \mathrm{~mm})$ zone of inhibition. The stem extract in the methanol solvent exhibits highest zone of inhibitory growth against K.pneumoniae with $(18 \mathrm{~mm})$ zone of inhibition while least antibacterial activity was recorded against B.fusiformis with 9.5 $\mathrm{mm}$ zone of inhibition (Agnihotri et al., 2012).

According to Verma and Kakkar (2010) reported the antibacterial effect of stem methanol extract of Tinospora cordifolia against pathogenic microorganisms (Escherichia coli, Staphylococcus aureus and Staphylococcus albus). Results showed that widest zone of inhibition $(14.4 \mathrm{~mm})$ were demonstrated by the methanolic extract of Tinospora cordifolia stem against E. coli via agar well diffusion methodas compared to paper disc method $(10 \mathrm{~mm})$. Jeyachandran et al. (2003)reported that antibacterial activity of the aqueous, ethanol and chloroform extracts from the stems of Tinospora cordifolia using disc diffusion method, measured in terms of inhibition (cm) against Escherichia coil, Proteus vulgaris, Enterobacter faecalis, Salmonella typhi (Gram-negative), Staphylococcus aureus and Serratia marcesenses (Grampositive). It revealed that the ethanolic extracts exhibited significant antibacterial activity against Proteus vulgaris, Escherichia coli and moderate activity was observed against Enterobacter faecalis. In the same extract less inhibition was observed against Salmonella typhi, Staphylococus aureus and Serratia marcescens.

Singh and Singh (2012) reported the antibacterial activities of Tinospora cordifolia (Willd) stem extract prepared with methanol (hot and cold) against bacterial strains Salmonella typhi, Staphylococcus aureus, Shigella dysenteriae, Escherichia coli and Pseudomonas aeruginosa. In vitro antibacterial activity of hot and cold methanol stem extracts was performed by cup plate agar diffusion method using ciprofloxacin in Dimethyl sulphoxide as a standard drug for the comparing antibacterial activity. Both Hot and cold methanol extracts of Tinosporacordifolia stem contain significant antibacterial activityagainst all test bacterial strains but hot methanol extractof T.cordifolia stem showed more significant activityagainst all tested bacterial organisms.

Mahesh and Satish (2008) reported thatthe leaf extract of Tinospora cordifolia showed maximum antibacterialactivity compared to other parts; methanolicextract of plant sample showed maximumactivity (Kakkar and Verma, 2011), and soluble fraction of themethanolic extract of plant showedantibacterial activity (Kawsaret al., 2011).

Forty nine different plantsused in traditional Indian medicine were examinedagainst Aspergillus niger using agar well diffusionmethod(Bobbarala et al., 2009). The methanolic extracts of 43 plants exhibitedvarying degrees of inhibition activity against the fungi.Among the forty nine plants studied, $86 \%$ of the plants hadantifungal activity, while the remaining $14 \%$ had noantifungal activity. The extract from Grewia arboreashowed maximum activity. Emblica officinales, Heldigordia populipolia, Hyptis sueolences, Moringa heterophylla, Strychnos nuxvomica and Vitex negundodid not exhibit antifungal activity against $A$. niger. 
Sharma and Trivedi (2002)studied fresh leaf extracts of Datura stramonium, Calotropis procera, Verbesenaenceloides, Parthenium hysterophorus, Morus alba, Phyllanthus amarus,Eichhornea crassipes, Ricinus communis, Jatropha curcas, Azadirachta indica, Tinospora cordifolia, Clerodendron multiflorum, Catharanthus roseus and Adhatoda vesica against root-knot nematode, Meloidogyne incognita and wilt fungus, Fusarium oxysporum f. sp. cumini infesting cumin. In the preliminary studies, almost all the plant species exhibited nematicidal and antifungal property. Calotropis procera and Ricinus communis gave best results against the nematodeand Datura stramonium and Calotropis procera showed maximum antifungalactivity against Fusarium oxysporum f.sp. cumini.

Issakul (2013) reported that application of botanical herbicides as one of alternative ways to reduce the use of harmful herbicides in agricultural pest management. Eighteen species of Thai local plant extracts i.e. Murraya paniculata (L.) Jack. leaf, Hydrocotyle umbellata L. leaf, Mammea siamensis T. Anders. seed, Duranta erecta L. leaf, Pluchea indica Less. leaf, Aglaia Odorata Lour. leaf, Leucaena leucocephala de wit. leaf, Ipomoea aguatica Forsk, Eucalyptus camaldulensis Dehnh leaf, Leea macrophylla Roxb.ex Hornem. leaf, Metha cordifolia Opiz. leaf, Casuarina junghohniana Mfg. leaf, Stemona curtisii. Hook.F. root, Cassis fistula Linn.pod, Tinospora crispa (L.) Miers ex Hook.f.\& Thoms.stem, Brachiaria mutica (Forsk.) Stapf leaf, Raphanus sativus var. longipinnatus L. root and Zollingeria dongnaiensis Pierre leaf were screened for the highest herbicidal activity in laboratory by the filter paper method. Aglaia odorata leaf extract demonstrated the highest germination inhibitory activity. It also had a highest significant efficiency to inhibit both root and shoot of Mimosa seedling. Aglaia odorata was selected for determination of its herbicidal efficiency under pot experiment. Aglaia odorata leaf extract at the concentration of $4 \% \mathrm{w} / \mathrm{v}$ exhibited stronger toxicity on germination and growth of Mimosa seedling than control (solvent) treatment in pot experiment.

Khan and Srivastava (2012) reported the water (at room temperature and at elevated temperature), $70 \%$ ethanol, $80 \%$ methanol, acetone, ethyl acetate and chloroform extracts of Tinospora cordifolia (Giloy) against bacterial pathogens such as Escherichia coli, Staphylococcus aureus and Pseudomonas aeruginosa using agar well diffusion method at $100 \mathrm{mg} / \mathrm{ml}$ concentration was evaluated for their antibacterial properties. Water (at room temperature and at elevated temperature), ethanolic and ethyl acetate extracts of Tinospora leaves showed an average inhibitory zone of $14 \mathrm{~mm}, 14.5 \mathrm{~mm}, 17 \mathrm{~mm}$ and $12.5 \mathrm{~mm}$ respectively which indicates that ethanolic extract shows best result having zone of inhibition more than that of tetracycline (12mm against all pathogens) while extracts of methanol, acetone and chloroform didn't show any result. In case of Tinospora stem and root best result was shown by hot aqueous extract with a zone of inhibition of $16 \mathrm{~mm}$ and $17 \mathrm{~mm}$ respectively. The ethanolic extract of root also gave a zone of $17 \mathrm{~mm}$.

Sankhala et al. (2012) revealed that Tinospora cordifolia is an excellent drug, which could be a good remedy for various ailments of animals as well as human beings yet the safety and potential indications in human beings and animals have to be established using modern techniques. Uddin et al. (2011) used Tinospora for isolation of its secondary metabolites andevaluation of biological activities with special emphasis to 
the antimicrobial screening and cytotoxic study. The chemical constituents have been reported from this shrub belong to different classes, such as alkaloids, diterpenoid lactones, glycosides, steroids, sesquiterpenoid, phenolics, aliphatic compounds and polysaccharides (Upadhyayet al., 2010).

Table.1 Chemistry of Tinospora cordifolia

\begin{tabular}{|c|c|c|c|}
\hline Part & Chemical type & Active principle & Reference \\
\hline \multirow{7}{*}{ Stem } & Alkaloids & $\begin{array}{l}\text { Berberine, palmatine } \mathrm{D} \text {, choline } \mathrm{D} \text {, } \\
\text { tinosporine, Magnoflorine, } \\
\text { tetrahydropalmatine, isocolumbin }\end{array}$ & $\begin{array}{l}\text { Padhya, 1986; Sarmaet } \\
\text { al., 1998; Kumaret al., } \\
2000\end{array}$ \\
\hline & \multirow{6}{*}{ Glycosides } & 18-norclerodane glycoside & Khanet al., 1989 \\
\hline & & Furanoid diterpene glycoside & $\begin{array}{l}\text { Bhatt and Sabata, 1989; } \\
\text { Swaminathanet al., } 1989\end{array}$ \\
\hline & & Tinocordiside & $\begin{array}{l}\text { Mauryaet al., 1995; } \\
\text { Ghosal and } \\
\text { Vishwakarma, } 1997\end{array}$ \\
\hline & & Syringin & $\begin{array}{l}\text { Sipahimalaniet al., 1994; } \\
\text { Kapil and } \\
\text { Sharma,1997 }\end{array}$ \\
\hline & & Syringin-apiosylglycoside & $\begin{array}{l}\text { Khanet al., 1989; Bhatt } \\
\text { and Sabata, } 1989\end{array}$ \\
\hline & & $\begin{array}{l}\text { Tinocordifolioside, cordioside, } \\
\text { cordifolioside A, cordifolioside B, } \\
\text { palmatoside C31, palmatoside F31, } \\
\text { cordiofoliside B2, cordifoliside D2, } \\
\text { cordifoliside }\end{array}$ & $\begin{array}{l}\text { Swaminathanet al., 1989; } \\
\text { Ghosal and } \\
\text { Vishwakarma, 1997; } \\
\text { Mauryaet al., } 1997\end{array}$ \\
\hline & Sesquiterpenoid & Tinocordifolin & $\begin{array}{l}\text { Maurya and Hardass, } \\
1998\end{array}$ \\
\hline Root & Alkaloid & Palmatine & Pathaket al., 1995 \\
\hline \multirow[t]{2}{*}{ Aerial parts } & Steroids & $\begin{array}{l}\text { b-sitosterol, d-sitosterol, g-sitosterol b- } \\
\text { hydroxyecdysone, ecdysterone, makisterone, } \\
\text { giloinsterol jateorine, columbin }\end{array}$ & $\begin{array}{l}\text { Pathaket al., 1995; } \\
\text { Ganganet al., } 1997\end{array}$ \\
\hline & $\begin{array}{l}\text { Diterpenoid } \\
\text { lactones }\end{array}$ & Furanolactone, tinosporon, columbin & $\begin{array}{l}\text { Hanumanet al.,1680; } \\
\text { Qudratet al., 1966; } \\
\text { Ahmadet al., 1978 }\end{array}$ \\
\hline \multirow[t]{2}{*}{ Whole plant } & $\begin{array}{l}\text { Aliphatic } \\
\text { compound }\end{array}$ & Octacosanol, heptacosanol & Dixit and Khosa, 1971 \\
\hline & $\begin{array}{l}\text { Miscellaneous } \\
\text { compound }\end{array}$ & $\begin{array}{l}\text { Nonacosan-15-one 3, (a,4-dihydroxy-3- } \\
\text { methoxy-benzyl)-4-(4-hydroxy-3-methoxy- } \\
\text { benzyl)-tetrahydrofuran, Tinosponidine, } 6 \\
\text { cordifol, } 6 \text { Cordifelone, } 6 \text { Jatrorrhizine }\end{array}$ & Khalequeet al., 1971 \\
\hline
\end{tabular}


Table.2 Action of some important phytochemicals of Tinospora cordifolia

\begin{tabular}{|c|c|c|c|}
\hline Phytochemicals & Activity & Mechanism of action & Reference \\
\hline Quinones & Antimicrobial & Binds to adhesions, complex with cell wall, inactivate enzymes & Cowan, 1999 \\
\hline \multirow[t]{2}{*}{ Flavanoids } & Antimicrobial & $\begin{array}{l}\text { Complex with cell wall, binds to adhesins Inhibits release of } \\
\text { autacoids and prostaglandins, }\end{array}$ & Cowan, 1999 \\
\hline & Antidiarrhoeal & $\begin{array}{l}\text { Inhibits contractions caused by spasmogens, Stimulates } \\
\text { normalization of the deranged water transport across the } \\
\text { mucosal cells, Inhibits GI release of acetylcholine }\end{array}$ & $\begin{array}{l}\text { Kumar et al., } \\
2010\end{array}$ \\
\hline \multirow[t]{3}{*}{$\begin{array}{l}\text { Polyphenols and } \\
\text { Tannins }\end{array}$} & Antimicrobial & $\begin{array}{l}\text { Binds to adhesions, enzyme inhibition, substrate deprivation, } \\
\text { complex with cell wall, membrane disruption, metal ion } \\
\text { complexation }\end{array}$ & Cowan, 1999 \\
\hline & Antidiarrhoeal & $\begin{array}{l}\text { Makes intestinal mucosa more resistant and reduces secretion, } \\
\text { stimulates normalization of deranged water transport across the } \\
\text { mucosal cells and reduction of the intestinal transit, blocks the } \\
\text { binding of B subunit of heat-labile enterotoxin to GM1, } \\
\text { resulting in the suppression of heat-labile enterotoxin-induced } \\
\text { diarrhea, astringent action }\end{array}$ & $\begin{array}{l}\text { Maniyaret al., } \\
\text { 2010; Kumar et } \\
\text { al., } 2010\end{array}$ \\
\hline & Antihelmintic & $\begin{array}{l}\text { Increases supply of digestible proteins by animals by forming } \\
\text { protein complexes in rumen, interferes with energy generation } \\
\text { by uncoupling oxidative phosphorylation, causes a decrease in } \\
\text { G.I. metabolism }\end{array}$ & $\begin{array}{l}\text { Sutar et al., } \\
\text { 2010; Patelet } \\
\text { al., } 2010\end{array}$ \\
\hline Coumarins & Antiviral & Interaction with eukaryotic DNA & $\begin{array}{l}\text { Vidyadhar et al., } \\
2010\end{array}$ \\
\hline \multirow{2}{*}{$\begin{array}{l}\text { Terpenoids and } \\
\text { essential oils }\end{array}$} & Antimicrobial & Membrane disruption Inhibits release of autocoids and & Cowan, 1999 \\
\hline & Antidiarrhoeal & prostaglandins & $\begin{array}{l}\text { Maniyaret al., } \\
2010\end{array}$ \\
\hline \multirow[t]{3}{*}{ Alkaloids } & Antimicrobial & Intercalates into cell wall and DNA of parasites & Cowan, 1999 \\
\hline & Antidiarrhoeal & Inhibits release of autocoids and prostaglandins & $\begin{array}{l}\text { Maniyaret al., } \\
2010\end{array}$ \\
\hline & Antihelmintic & $\begin{array}{l}\text { Possess anti-oxidating effects, thus reduces nitrate generation } \\
\text { which is useful for protein synthesis, suppresses transfer of } \\
\text { sucrose from stomach to small intestine, diminishing the } \\
\text { support of glucose to the helminthes, acts on CNS causing } \\
\text { paralysis }\end{array}$ & $\begin{array}{l}\text { Mute et al., } \\
\text { 2009; Mali et } \\
\text { al., } 2007\end{array}$ \\
\hline $\begin{array}{l}\text { Lectins and } \\
\text { Polypeptides }\end{array}$ & Antiviral & Blocks viral fusion or adsorption, forms disulfide bridges & $\begin{array}{l}\text { Vidyadhar et al., } \\
2010\end{array}$ \\
\hline Glycosides & Antidiarrhoeal & Inhibits release of autocoids and prostaglandins & $\begin{array}{l}\text { Maniyaret al., } \\
2010\end{array}$ \\
\hline \multirow[t]{3}{*}{ Saponins } & Antidiarrhoeal & Inhibits histamine release in vitro & $\begin{array}{l}\text { Maniyaret al., } \\
2010\end{array}$ \\
\hline & Anticancer & Possesses membrane permeabilizing properties & $\begin{array}{l}\text { Shaibani et al., } \\
2009\end{array}$ \\
\hline & Antihelmintic & Leads to vacuolization and disintegration of teguments & $\begin{array}{l}\text { Sharma et al., } \\
\text { 2010a }\end{array}$ \\
\hline Steroids & Antidiarrhoeal & Enhance intestinal absorption of $\mathrm{Na}+$ and water & $\begin{array}{l}\text { Maniyaret al., } \\
2010\end{array}$ \\
\hline
\end{tabular}




\section{Growth Regulatory Activities of Different Extracts of Tinospora cordifolia on Some Food Crops}

There are different types of plant such as herbal or medicinal, fruit trees, woody, necrotic, herbaceous, shrubs, weeds etc. in plant kingdom. Most of them have effective medicinal values, growth regulatory, herbicidal and pesticidal effects and also toxic values. According to $\mathrm{WHO}$, around $80 \%$ of the world's 5.86 billion inhabitants depend on traditional medicine for their primary health care, majority of which use plant or their active principles (Gias Uddin, 1998). The attention is being needed to the importance of rotation in medicinal plant or between medicinal herbs and other crops (Basotra et al., 2005; Guo et al., 2006; Nazir et al., 2007). Various types of extracts of $T$. cordifolia and Shial mutra having bioactive compound increase or decrease germination and growth rate of crops (Roy et al., 2004; Roy, 2006).

Aktar et al. (2012) investigated the growth regulatory activities of different extracts of Tinospora cordifolia on radish (Raphanus sativus), swamp cabbage (Impoea aquatica) and lady's finger (Hibiscus esculentus) with the attempt for chemical investigation of effective plant extract. The chloroform extract of Tinospora cordifolia significantly increased and enhanced germination, growth of shoot length and root length of radish and lady's finger whereas and delayed germination, growth of shoot length and root length of swamp cabbage seeds compared with control. In the same way, ethanol extract of Tinospora cordifolia significantly increased germination, growth of shoot length and root length of swamp cabbage followed by control and chloroform extract. The different extracts of Tinospora cordifolia contain growth regulatory active principle. Among the extracts, chloroform extract showed better performance in terms of percent germination, growth of shoot and root length of radish and lady's finger whereas according to Singh et al. (2009) conducted to estimate the allelopathic effects of Tinospora cordifolia on food crops and obtained result that higher concentration of leaf and old shoot extracts inhibited the germination of Sesamum orientala and Eleusine coacana while higher concentration stimulate the germination of Cajanus cajan. The lower concentration of new shoots stimulates germination as compared to higher concentration. The higher concentration of leaf, new shoot and old shoot had suppressed radicle and plumule growth of all tested food crops as compared to lower concentration.

On the other hand, according to Raoof and Siddiqui (2011) studied the allelopathic effects ofLeaf and stem aqueous extracts ofTinospora cordifolia weed on seed germination and seedling growth of weed plants (Chenopodium album L. Chenopodium murale L., Cassia tora L. and Cassia sophera L.) at 0.5 to $4.0 \%$ concentrations. Aqueous extracts from leaf and stem inhibited germination, root length, shoot length and dry weight of weed species decreased progressively when plants were exposed to increasing concentration $(0.5,1$, 2 and 4\%). Aqueous extract of leaves shows the maximum inhibition while stem shows the least affect on weeds.

In conclusion, the scientific research on $T$. cordifolia suggests a huge biological potential of this plant. It is widely used in ayurvedic medicine for the treatment of various ailments. It is strongly believed that detailed information as presented in this review on biological and microbial properties of the extracts might provide detailed evidence for the use of this plant in different medicines. Antimicrobial potential 
shown by these plants further warrant their exploration for the development of novel effective chemotherapeutic agents. $T$. cordifolia is an excellent drug, which could be a good remedy for various ailments of animals as well as plants, yet the safety and the potential indications in human beings and animals have to establish using modern techniques.

\section{References}

Agnihotri, A., K. Kumar, A. Srivastava andS. Bhadauria, 2012. Antibacterial potentialof Tinospora cordifolia against resistant human pathogenic bacteria. Inter. J. Pharmacy and Pharmaceut. Sci., Vol 4, Suppl 5: 146-147.

Aher, V.D., A.K. Wahi. 2010. Pharmaco-logical Study of Tinospora cordifolia as an Immunomodulator, Inter. J. Curr. Pharmaceut. Res., 2: 4.

Ahmad, M., A.B. Kazi, R. Karim, A. Khaleque, M.A.W. Miah. 1978. Structure of tinosporide, a furanoid diterpene from Tinospora cordifolia. J. Bangladesh Academy of Sci., 2: 25- 30.

Ahmad, S.M., H.B. Hoot, P.H. Qazi, V. Verma. 2009. Phylogenetic patterns and genetic diversity of Indian Tinospora species based on chloroplast sequence data and cytochrome P450 polymorphisms. Plant Syst. Evol., 281: 87-96.

Aktar, S., M.A. Sayed, M.R. Islam, B. Roy, M.A. Hossain. 2012. Growth Regulatory Activities of Different Extracts of Tinospora Cordifolia on Some Vegetable Seeds with their Chemical Investigation. J. Environ. Sci. Natural Res., 5(1): 133-140.

Al-Shamaony, L., S.M. Al-Khazraji, H.A.A. Twaij. 1994. Hypoglycaemic effect of Artemisia herba alba. II: Effect of a valuable extract on some blood parameters in diabetic animals. J. Ethnopharmacol., 43 (3): 167171.

Anon, 1956. The Wealth of India: Raw Materials, Council of Scientific and Industrial Research, New Delhi. vol. X, pp. 251-252.

Atal, C.K., M.L. Sharma, A. Kaul, A. Khajuria,.1986. Immunomodulating agents of plant origin, preliminary screening. $J$. Ethnopharmacol., 18: 133.
Bachaya, H.A., I. Iqbal, M.N. Khan, J. Jabbar, A.H. Gilani, I.U. Din. 2009. Invitro and In vivo antihelmintic activity of Terminalia arjuna bark. Inter. J. Agric. Biol., 11: 273278.

Badar, V.A., V.R. Thawani, P.T. Wakode, M.P. Shrivastava, K.J. Gharpure, L.L. Hingorani, R.M. Khiyani. 2005. Efficacy of Tinospora cordifolia in allergic rhinitis. $J$. Ethnopharmacol., 96: 445-449.

Bafna, P.A., R. Balaraman. 2005. Anti-ulcer and anti-oxidant activity of pepticare, a herbomineral formulation. Phytomedicine, 12: $264-70$.

Balunas, M.J., A.D. Kinghorn. 2005. Drug discoveryfrom medicinal plants. Life Sci., 78: 431-441.

Bansal, D., P. Bhasin, A. Punia, A.R. Sehrawat. 2012. Evaluation of antimicrobial activity and phytochemical screening of extracts of Tinospora cordifolia against somepathogenic microbes. J. Pharmacy Res., 5(1): 127.

Basotra, R., S. Chauhan, N.P. Todaria. 2005. Allelopathic effects of medicinal plantson food crops in Garhwal, Himalaya. $J$. Sustainable Agri., 26: 43-56.

Bhattacharya, S.K., K.S. Satan, A. Chakrabarti. 1997. Effect of Trasina, an Ayurvedic herbal formulation on pancreatic islet superoxide dismutase activity in hyperglycaemic rats. Indian J. Exp. Biol., 35(3): 297.

Bhatt, R.K., B.K. Sabata. 1989. Furanoid diterpene glucoside from Tinosporacordifolia. Phytochem., 28: 2419-2422.

Bhengraj, A.R., S.A. Dar, G.P. Talwar, A. Mittal. 2008. Potential of a novel polyherbal formulation BASANT for prevention of Chlamydiatrachomatis infection. Inter. J. Antimicrobial Agents, 32: 84-88.

Bishayi, B., S. Roychowdherry, S. Ghosh, M. Sengupta. 2002. Hepatoprotective and immunomodulatory properties of Tinospora cordifolia in $\mathrm{CCl}_{4}$ intoxicated mature albino rats. J. Toxicol. Sci., 27(3): 139-146.

Bisset, N., J. Nwaiwu. 1983. Planta Med., 48: 275-279.

Bobbarala, V., P.K. Katikala, K.C. Naidu, S. Penumajji. 2009. Antifungal activity of selected plant extracts against phytopathogenic fungi Aspergillus niger F2723. Indian J. Sci. Technol., 2(4): 87-90.

Bousquet, J., M. Bullinger, C. Fayol, P. Marquis, B. Valentin, B. Burtin. 1994. Assessment of 
quality of life in patients with perennial allergic rhinitis with the French version of the SF-36 Health Status Questionnaire. J. Allergy Clin. Immunol., 94(1): 182-188.

Chaudhary, R., S. Jahan, P.K. Goyal. 2008. Chemopreventive potential of an Indianmedicinal plant (Tinospora cordifolia) on skin carcinogenesis. $J$. Environ. Pathol. Toxicol., 27: 233-243.

Chintalwar, G., A. Jain, A. Sipahimalani, A. Banerji, P. Sumariwalla, R. Ramkrishna,K. Sainish. 1999. An Immunologically active arabinogalactan from Tinospora cordifolia, Phytochem., 52: 1089.

Cowan, M.M. 1999. Plant products as antimicrobial agents. Clin. Microbiol. Rev., 12(4): 564-582.

Desai, V.R., J.P. Kamat, K.B. Sainis. 2002. An immunomodulatory from Tinospora cordifolia with antioxidant activity in cellfree systems. Proceeding of Indian Acadamy of Science, (Chemical Science) 114: 713-719.

De Toledo, C.E.M., E.A. Britta, L.F. Ceole, E.R. Silva, J.C.D. De Mello, B.P.D. Filho. 2011. Antimicrobial and cytotoxic activities of medicinal plants of the Brazilian cerrado, using Brazilian cachac, a as extractor liquid. J. Ethnopharmacol., 133: 420-425.

Dhuby, J.N. 1997. Effect of some Indian herbs on macrophage functions in Ochraloxin treated mice. J. Ethnopharmacol., 58: 15-20.

Dixit, S.N., R.L.Khosa, 1971. Chemical investigation of Tinospora cordifolia.Indian J. Appl. Chem. 34 (1): 46-47.

Dorman, H.J.D., S.G. Deans, 2000. Antimicrobial agents from plants: antibacterialactivity of plant volatile oils.J. Appl. Microbiol.88: 308316.

Duraipandiyan, $\quad$ V., $\quad$ S. Ignacimuthu, 2011.Antifungal activity of traditional medicinal plants from Tamil Nadu, India. Asian Pacific J. of Tropical Biomedicine S204-S215.

Drahl, C., B.F. Cravatt, E.J. Sorensen, 2005. Protein-reactive natural products. Angew Chem. Int. Ed. Engl. 44: 5788-5809.

Duru, M.E., A. Cakir, S. Kordali, H. Zengin, M. Harmandar, S. Izumi, T. Hirata, 2003. Antifungal activities of the leaves of three Pistacia species grown in Turkey. Fitoterapia 74 (1-2): 170- 176.

Duraipandiyan, V., S. Ignacimuthu, M.
Gnanasekaran, 2010. Antifungal activity of triterpenoid isolated from Azima tetracantha leaves. Folia Histochem Cytolbia 48: 311313.

Dwivedi, S.K., Enespa, 2012. Effectiveness of extract of some medicinal plants against soilborne fusaria causing diseases on Lycopersicon esculantum and Solanum melongena plants. Int. J. Pharm. Bio Sci. 3(4): $1171-1180$.

Fan, S.R., X.P. Liu, J.W. Li, 2008. Clinical characteristics of vulvovaginal candidiasis and antifungal susceptibilities of Candida species isolates among patients in southern China from 2003 to 2006. J.Obstet Gynaecol Res.34(4): 561-566.

Farooqi, A.A., B.S. Seeramu, 2001. Cultivation of medicinal and aromatic crops. University Press, New Delhi, pp 518.

Fortes, T.O., D.S. Alviano, G. Tupinamba, T.S. Padron, A.R. Antoniolli, C.S. Alviano, 2008. Production of an antimicrobial substance against Cryptococcus neoformans by Paenibacillus brasilensisSa3 isolated from the rhizosphere of Kalanchoe brasiliensis. Microbiol.Res. 163: 200-207.

Gangan, V.D., P. Pradhan,A.T. Sipahimalani, 1997. Indian J. Chem. Sci. 36: 787.Norrby, S.R., Nord, C.E., Finch, R. (2005). Lack of development of new antimicrobial drugs: a potential serious threat to public health. Lancet Infect. Dis. 5:115-119.

Gangan, V.D., P. Pradhan, A.T. Sipahimalani, A. Banerji, 1995. Norditerpene furan glycosides from Tinospora cordifolia. Phytochem.39: 1139-1142.

Ghosal, S., R.A. Vishwakarma, 1997. Tinocordiside, a new rearranged cadinane sesquiterpene glycoside from Tinospora cordifolia. J. of Natural Product 60: 839841.

Goel, H.C., P.I. Kumar, S.V. Rana, 2002. Free radical scavenging and metal chelation by Tinospora cordifolia, a possible role in radioprotection. Indian J. of Experimental Biol. 40(6): 727-734.

Goel, H.C., J. Prasad, S. Singh, R.K. Sagar, P.K. Agrawala, M. Bala, A.K. Sinha, R. Dogra, 2004. Radioprotective potential of an herbal extract of Tinospora cordifolia. J. Radiat. Res.45(1): 61-68.

Guo, B.H., Y.C. Wang, X.W. Zhou, K. Hu, F. Tan, Z. Miao, K.X. Tang, 2006. Anendophytic 
Taxol-producing fungus BT2 isolated from Taxus chinensis var. mairei. Af.J. Biotech. 5(10): 875-877, (2006).

Gupta, S.K., A.B. Banerjee, 2008. Screening of selected West Bengal plants for antifungalactivity.Econ. Bot. 26(3): 255-259.

Hanuman, J.B., R.K. Bhatt,B.K. Sabata, 1680.A diterpenoid furano lactone from Tinospora cordifolia. Phytochem. 25: 1677-1680.

Hooker, J.D. 1875. Flora of British India, L Reeve \& Co. London vol. I, pp. 96-97.

Ikram, M., S.G. Khattak, S.N. Gilani, 1987. Antipyretic studies on some indigenous Pakistani medicinal plants: II. $J$. Ethnopharmacol., 19: 185-92.

Isman, M.B., 2000. Plant essential oils for pest and disease management. Crop Prot., 19: 603608.

Issakul,K., 2013. Herbicidal Efficiency of Aglaia odorata Extracts Against Mimosa pigra L. American J. of Res. Communication 1(5): $238-244$.

Iwu, M.W., A.R. Duncan,C.O. Okunji, 1999. New antimicrobials of plant origin In: Janick, J. (Ed.), Perspectives on New crops and New Uses. ASHS Press, Alexandr, VA, pp: 457462.

Jagetia, G.C.,S.K. Rao, 2006. Evaluation of cytotoxic effect of Dichloromethane extract of Guduchi on cultured Hela Cells. Evidence-based complement-tary and alternative medicine 3:267-272.

Jagetia, G.C., S.K. Rao, 2006. Evaluation of antineoplastic activity of Guduchi Enrichascites carcinoma bearing mice. Biol. Pharm. Bull. 29: 460-466.

Jain, S., B. Sherlekar, R. Barik, 2010.Evaluation of antioxidant potential of Tinospora cordifolia and Tinospora sinensis. Int. J. Pharm. Sci. Res. 1(11) 122-8.

Jana, V., R.N. Chattopadhyay, B.P. Shw, 1999.Preliminary studies on antiinflammatory activity of Zingiber officinale Rose, Vitex negundo Linn and Tinospora cordifolia (Wild) Miers in albino rats. Indian J. of Pharmacol. 31: 232-233.

Jeyachandran, R., T.F. Xavier,S.P. Anand, 2003. Antibacterial activity of stem extracts of Tinospora cordifolia (willd) hook. F \& Thomson. Ancient Science of Life. XXIII (1).

Jeyachandran, R., T. Francis Xavier,S.P. Anand, 2003. Antibacterial activity of stem extracts of Tinospora cordifolia. (Willd) Hook.f\&
Thomson. Ancient Science ofLife Vol: XXIII(1), pp. 40-43.

Kapil, A.,S. Sharma, 1997.Immuno potentiating compounds from Tinospora cordifolia. J. Ethnopharmacol.58: 89-95.

Kawsar, H., A. Hossai, H. Uddin, 2011. Antimicrobial and cytotoxic activity of Tinospora cordifolia (Family: Menispermaceae), Int. J. Pharma Sci. Res. 2(3):656-658.

Khan, M.A., A.L. Gray, P.G. Waterman, 1989.Tinosporaside, an 18- norclerodane glucoside from Tinospora cordifolia.Phytochem., 28: 273- 275.

Khan, J.A., R. Srivastava, 2012. A Study on antibacterial properties of Tinospora cordifolia stem, root. Inter. J. of Pharmaceuti. Res. and Bio-Sci., 1(6): 291298.

Khaleque, A., M.A.W. Miah, M.S. Huq, B.K. Abdul, 1971. Tinospora cordifolia. IV. Isolation of heptacosanol, b -sitosterol and three other compounds tinosporidine, cordifol and cordifolone. Pak. J. Sci. Ind. Res. 14: 481-483.

Kirtikar, K.R., B.D. Basu, 1981. Indian Medicinal Plants, Lalit Mohan Basu, Allahabad vol. I, pp. $75-80$.

Kim, E., K. Hammond,J.D.G. Jones, 1996. Resistance Gene-Dependent Plant Defense Responses. The Plant Cell 8: 1773-1791.

Koehn, F.E., G.T. Carter, 2005. The evolving role of natural products in drug discovery.Nat. Rev. Drug Discov. 4: 206-220.

Kulkarni, S.K., A. Verma, 1993. A herbal preparation improves learning and memory performance in mice. Indian drugs 30:97.

Kumar, R., R.J. Sharma, K. Bairwa ,R.K. Roy, A. Kumar, 2010. Pharmacological review on natural antidiarrhoel agents. Der. Pharma Chemi. 2(2): 66-93.

Kumar, S., N.S. Verma, D. Pande, P.S. Srivastava, 2000. In vitro regeneration and screening of berberine in Tinospora cordifolia. J. Medi. Aromatic Plant Sci. 22: 61.

Kumar, S.,V.P. Menon, 1992. Antioxidant action of Tinospora cordifolia root extract in alloxan diabetic rats. Indian J. of Medical Res.96: 176.

Leyon, P.V., G. Kuttan, 2004. Inhibitory effect of a polysaccharide from Tinospora cordifolia on experimental metastasis. $J$. Ethnopharmacol. 90 (2-3): 233-237. 
Mahesh, B. and S.R. Satish, 2008.Antimicrobial activity of some important medicinal plants against plant and animal pathogens. W. J. Agric. Sci., 4(5): 839-843.

Maniyar, Y., P. Bhixavatimath, N.V. Agashikar, 2010. Antidiarrheal activity of flowers of Ixora Coccinea Linn.In rats.J. Ayurveda Integr Med. 1: 287-291.

Mali, R.G., S.G. Mahajan,A.A. Mehta, 2007. Invitro antihelmintic activity of stem bark of Mimusops elengi Linn.Pharmacognosy Magazine. 3(10): 73-76.

Manjreker, P.N., C.I. Jolly, S. Narayanan, 2000. Comparative studies ofimmunomodulatory activity of Tinospora cordifolia and $T$. sinensis. Fitoterapia71:254.

Mathur, A., R. Singh, S. Yousuf, A. Bhardwaj, S.K. Verma, P. Babu, V. Gupta, G.B.K.S. Prasad, V.K. Dua, 2011. Antifungal activity of some plant extractsagainst Clinical Pathogens. Advances in Applied Sci. Res. 2 (2): 260-264.

Maurya, R., S.S. Handa, 1998. Tinocordifolin, a sesquiterpene from Tinospora cordifolia. Phytochem.1343-1345.

Maurya, R., K.L. Dhar, S.S. Handa, 1997. A sesquiterpene glucoside from Tinospora cordifolia. Phytochem.44: 749-750.

Maurya, R., Hardass, 1998.Tinocordifolin, a sesquiterpene from Tinospora cordifolia. Phytochem. 49: 1343-6.

Maurya, R., V. Wazir, A. Tyagi,R.S. Kapil, 1995. Clerodane diterpenoids from Tinospora cordifolia Phytochem. 38: 559-61.

Maurya,R., V. Wazir, A. Tyagi, R.S. Kapil, 1995. Clerodane diterpenoids from Tinospora cordifolia.Phytochem.38: 659-661.

Mehrotra, R., C.K. Katiyar, A.P. Gupta, 2000. Hepato protective compositions and composition for treatment of conditions related to hepatitis $\mathrm{B}$ and $\mathrm{E}$ infection. Us Patent 749296-2000.

Methew,S.,G. Kutta, 1997. Antioxidant activities of Tinospora cordifolia and its usefulness in the amelioration of cyclophosphamide induced toxicity. J. Exp. Clin. Cancer Res. 16:407.

Mia, M.M.K., M.F. Kadir, M.S. Hossan,M. Rahmatullah, 2009. Medicinal plantsof the Garo tribe inhabiting the Madhupur forest region of Bangladesh.

Mittal, A., R.P. Singh, 2008. Anticancer and immunomodulatory properties of Tinospora cordifplia. In: KG Ranawat., editor. herbal drugs: Ethnomedicine to modern medicine. Berlin Heidelberg: p. 195.

Mukhopadhyay, A.N., 1996. Presidential address, Agricultural Science, 83 rd Indian. Science Congress, Patiala 1- 16.

Mute, V.M., 2009. Antihelmintic effect of Tamarind indica linn leaves juice exract on Pheretima posthuma. Inter. J. of Pharma Res. and Development 7: 1-6.

Nazir, T.A., K. Uniyal,N.P. Todaria, 2007. Allelopathic behaviour of three medicinal plant species on traditional agriculture crops of Garhwal Himalaya, India. Agroforestry Systems, 67:183-187.

Nile, $\quad$ S.H.,C.N.N. Khobragade, 2009. Determination of nutritive value and mineralelements of some important medicinal plants from western part of Indian J. Med. Plants, 8(5): 79-88.

Padhya, M.A., 1986. Biosynthesis of Isoquinoline alkaloid berberine in tissue cultures of Tinospora cordifolia Indian drugs 24: 47-8.

Pandey, R., A. Kalra , S. Tandon, N. Mehrotra, N.H. Singh, S. Kumar, 2000. Essential oils as potent sources of nematicidal compounds.J. Phytopathol., 148: 501- 502.

Pathak, A.K., P.K. Agarwal, D.C. Jain, R.P. Sharma, O.W. Howarth, 1995. NMRstudies of 20b-hydroxy ecdysone, a steroid, isolated from Tinospora cordifolia. Indian J.Chem. Sci. 34: 674-6.

Patel, J., G.S. Kumar, M.S. Qureshi, P.K. Jena, 2010. Antihelmintic activity of ethanolic extract of whole plant of Eupatorium odoratum.Inter. J. of Phytomedicine 2: 127132.

Pendse, V.K., M.M. Mahavir, K.C. Khanna, S.K. Somani, 1981.Anti-inflammatory and related activity of Tinospora cordifolia (Neem giloe). Indian drugs, 19: 14-71.

Portillo, A., R. Vila, B. Freixa, T. Adzet, S. Canigueral, 2001. Antifungal activity ofParaguayan plants used in traditional medicine. J.Ethnopharmacol.76: 93-98.

Premila, M.S., 2006. Ayurvedic Herbs: A clinical Guide to the Healing Plants of Traditional Indian Medicine. New York: Haworth Press pp. 69-76, 175-176.

Prince, P.S.M., V.P. Menon, G. Gunasekaran, 1998. Hypolipidaemic action ofTinospora cordifolia roots in alloxan diabetic rats. $J$. of Ethnopharmacol.64: 53- 57. 
Prince, P.S., M. Padmanabhan, V.P. Menon, 2004. Restoration of antioxidant defenceby ethanolic Tinospora cordifolia root extract in alloxan-induced diabetic liver andkidney. Phytotherapy Res. 18(9):785-787.

Prajapati, N.D., T. Prajapati, S. Jaipura, 2005.Advances in Medicinal Plants. AsianMedicinal Plants and Health Care Trust Publishers, 1: 222p.

Purandare, H., A. Supe, A. Statistics, R. Comments, 2007. Immunomodulatory role of Tinospora cordifolia as an adjuvant in surgical treatment of diabetic foot ulcers: A prospective randomized controlled study. Indian J. Med. Sci. 61: 347-55.

Qudrat-I-Khuda, M., A. Khaleque, A. Bashir, M.D.A. Roufk, N. Ray, 1966.Studies on Tinospora cordifolia - Isolation of tinosporon, tinosporic acid and tinosporolfrom fresh creeper.Scientific Res. 3: 9-12.

Raghu, R., D. Sharma, R. Ramakrishnan, S. Khanam, G.J. Chintalwar, K.B. Sainis, 2009. Molecular events in the activation of B cells and macrophages by a non-microbial TLR4 agonist, G1-4A from Tinospora cordifolia.Immunol.Lett., 123 (1): 60-71.

Rao, P.R., V.K. Kumar, R.K. Viswanath, G.V. Subbaraju, 2005. Cardioprotective activity of alcoholic extract of Tinospora cordifolia in ischemia-reperfusion inducedmyocardial infarction in rats. Biol. Pharm. Bull. 28(12): 2319-2322.

Raoof, K.M.A., M.B. Siddiqui, 2011. Allelopathic effect of aqueous extracts of different parts of Tinospora cordifolia (Willd.) Miers on some weed plants. J. of Agri. Extension and Rural Development 4(6): 115-119.

Rathi, S.S., J.K. Grover,V. Vats, 2002. The effect of Momordica charantia and Mucuna pruriens in experimental diabetes and their effect on key metabolic enzymes involved in carbohydrate metabolism. Phytotherapy Res. 16: 236-243.

Rawal, A.K., M.G. Muddeshwar, S.K. Biswas, 2005. Rubia cordifolia, Fagonia cretica linn and Tinospora cordifolia exert neuroprotection by modulating the antioxidantsystem in rat hippocampal slices subjected to oxygen glucose deprivation. feedbak.

Reddy, B.P., V.K. Murthy, V. Venkateshwarlu, C.K. Kokate,D. Rambhau,
1993.Antihepatotoxic activity of Tinospora cordifolia, Phyllanthus niruri and Ricinus communis. Indian Drugs 30(7): 338.

Rhoads, G.G., C.L. Gulbrandese,A. Kagan, 1976. Serum lipoproteins and coronaryartery disease in a population study of Hawaiian Japanese men. New England J. Med,294: 293.

Ropper, A.H., 2009. Dementia and the amnesic (Korsakoff) syndrome with commentson the neurology of intelligence and memory. In: Ropper AH, et al. (9eds.) Adams and Victor's Principles ofNeurology. McGraw-Hill, New York, pp. 444-463.

Roy, B., M.N. Uddin, M.J. Islam, R. Amin, A.T.M.S. Islam, B.C. Halder, 2004. Leaf Extracts of Shiyalmutra (Biumea laera De) as botanical inseticides against lessergrain borer and rice weevil. J. of Biol. Sci. 40: 1-2.

Roy, S.R., 2006. Biological activity of leaves of some ornamental plants with emphasis on chemical investigation. MS Thesis, Department of Agricultural Chemistry andBiochemistry, Hajee Mohammad Danesh Science and Technology University, Dinajpur.

Sankhala, L.N., R.K. Saini,B.S. Saini, 2012. A review on chemical and biologicalproperties on Tinospora cordifolia.Inter. J. Med. Arom Plants.

Sarma, D.N.K., R.L. Khosa, J.P.N. Chaurasia,M. Sahai, 1996. Antistress activity of Tinospora cordifolia and Centella asiatica extracts. Phytotherapy Res. 10:181.

Shaibani, T.R.M.A., M.S. Phulan,M. Shiekh, 2009. Antihelmintic activity of Fumaria parviflora (Fumariaceae) against gastrointestinal nematodes of sheep.Int. J.Agric. Biol. 11: 431-436.

Sharma, U.S., U.K. Sharma, A. Singh, N. Sutar,P.J. Singh, 2010a.In vitroantihelmintic activity of Murraya koenigii linn.Leaves extracts. Inter. J. of Pharma andBio Sci. 1(3): $1-4$.

Sharma, A., A. Gupta, S. Singh, A. Batra, 2010c. Tinospora cordifolia (Willd.)Hook. F. \& Thomson - A plant with immense economic potential. J. Chem. Pharm. Res. 2(5): 327333.

Sharma, N.,P.C. Trivedi, 2002. Screening of Leaf Extracts of Some Plants for TheirNematicidal and Fungicidal Properties against Meloidogyneincognita and Fusarium 
oxysporum. Asian J. Exp. Sci.16(1-2): 21-28. Sharma, S., N. Rathi, B. Kamal, D. Pundir, K. Baljinder,A. Sarita, 2010.Conservation of biodiversity of highly important medicinal plants of India through tissueculture technique-a review Agri. Bio. J.N. Am. 1(5): 827-833.

Sarma, D.N.K., R.L. Khosa, J.P.N. Chaurasia, M. Sahai, 1995. Antiulcer activity of Tinospora cordifolia meirs and Centella asiatica linn.extracts. Phytotherapy Res. 9:589.

Sarma, D.N.K., P. Padma, R.L. Khosa, 1998. Constituents of Tinospora cordifolia root. Fitoterapia, 69(6): 541-542.

Shukla, S., J. Gardner, 2006. Local knowledge in community-based approaches to medicinal plant conservations: Lessons from India. $J$. Ethnobiol. Ethnomed. 2: 20.

Singh, J., K. Sinha, A. Sharma, N.P. Mishra,S.P. Khanuja, 2003. Traditional usesof Tinospora cordifolia (Guduchi).J. Med. Aromat. Plant Sci. 25: 748-51.

Singh, N., S.M. Singh, P. Shrivastava, 2005. Efect of Tinospora cordifolia on the anti-tumor activity of tumor-associated macrophages derived dendrite cells. Immunopharmacol. Immunotoxicol., 27(1): 1-14.

Singh, S.S., S.C. Pandey, S. Srisvastava, V.S. Gupta, B. Patro, A.C. Ghosh, 2003. Chemistry and Medicinal properties of Tinospora cordifolia (Guduchi).Indian J. Pharmacol., 35: 83-91.

Singh, S.,P. Singh, 2012. Effectiveness of Tinospora cardifoliastem extract on bacteria Salmonella typhi, Pseudomonas aeruginosa, Staphylococcus aureus and Shigella dysenteriae. Inter. J. of Pharma and Life Sci. 3: 1923-1925.

Singh, B., V. Singh,M. Kumar, 2009.Effect of Tinospora cordifolia Aqueous Extract on Traditional Food Crops of Garhwal Himalaya. Inter. J. of Sustainable Agri. 1(2): 36-40.

Singh, R.P., S. Banerjee, P.V. Kumar, K.A. Raveesha, A.R. Rao, 2006.Tinosporacordifolia induces enzymes of carcinogen/drug metabolism and antioxidant system, and inhibits lipid peroxidation in mice. Phytomedicine 13: 7484.

Singh, S., R. Srivastava, S. Choudhary, 2010.Antifungal and HPLC analysis of thecrude extracts of Acorus calamus,
Tinospora cordifolia and Celestrus paniculatus. J. of Agri.Technol. 6(1): 149158.

Sipahimalani, A.T., H. Noerr,H. Wagnor, 1994. Phenyl propenoid glycosides andtetrahydro furanlignan glycosides from the adaptogenic plant drugs Tinospora cordifolia and Drypetes rox burghii. Planta Medica. 60: 596-597.

Sivakumar, G.,K.V. Krishnamurthy, 2002. Gloriosa Superba L. - a very useful medicinal plant .In: Singh, V.K., J.N. Govil, S.Hashmi, and G.Singh (eds). RecentProgress in Medicinal Plants, Vol.7.Ethnomedicine and Pharmacognosy, Part II.Texas: Series Sci. Tech. Pub. Texas, USA.

Soliman, K.M., R.I. Badeaa, 2000. Effect of oil extracted from some medicinal plants on different mycotoxigenic fungi. Food Chem. and Toxicol.40: 1669- 1675.

Sohni, Y.R., P. Kaimal,R.M. Bhatt, 1995. The antiamoebic effect of a crude drug formulation of herbal extracts against Entamoeba histolytica in vitro and in vivo. J. Ethnopharmacol.45: 43.

Srivastava, P., 2011. Tinospora cordifolia (Amrita)- A miracle herb and lifeline to many diseases. Inter. J. of Medicinal and Aromatic Plants 1(2):57-61.

Stanely, P., M. Prince, V.P. Menon, 2000.Hypoglycaemic and other related actions of Tinospora cordifolia roots in alloxan-induced diabetic rats. $J$. of Ethnopharmacol.70(1): 9-15.

Stanely, M.P.P., M. Prince, V.P. Menon, 2001. Antioxident action of Tinospora cordifolia root extract in alloxan diabetic rats. Phytotherapy Res. 15 (3): 213-218.

Stanely, P., M. Prince,V.P. Menon, 2003. Hypoglycemic and hypolipidemic action of alcohol extract of Tinospora cordifolia roots in chemical induced diabetes in rats. Phytother. Res. 17: 410-413.

Sutar, N., R. Garai, U.S. Sharma, U.K. Sharma, 2010. Antihelmintic activity of Platycladus orientalis leaves extract. Inter. J. of Parasitol.Res. 2(2): 1-3.

Swaminathan, K., U.C. Sinha, R.K. Bhatt, R.B.K. Sabuta, S.S. Tavale, 1989.Structure of Tinosporide, a diterpenoid furanolactone from Tinospora cordifolia miers. Acta crystallogm 45: 134-6. 
Talbot, G.H., J. Bradley, J.E.J. Edwards, D. Gilbert, M. Scheld, J.G. Bartlett, 2006. Bad bugs need drugs: An update on the development pipeline from the antimicrobial availability task force of the infectious diseases society of America. Clin. Infect. Dis.42: 657-668.

Tharkar, P.R., A.U. Tatiya, P.R. Shinde, S.J. Surana, U.K. Patil, 2010. Antifungal activity of Glycyrrhiza glabra Linn.andEmblicaofficinalis Gaertn. by eirectbioautography method. Inter. $J$. PharaTech. Res.2: 1547-1549.

Thatte, U.M., S.A. Dahanukar, 1986.Ayurveda and contemporary scientific hought.Trends in Pharmacol.Sci. 7: 247- 251.

The Ayurvedic Pharmacopoeia of India, 2001. Part I. First Edition Vol. 1. New Delhi: Department Of AYUSH, Ministry of Health and FW. pp. 53-5.

Uddin, M.H., M.A. Hossain, M.H. Kawsar, 2011. Antimicrobial and cytotoxic activities of Tinospora cordifolia (FAM: Menispermaceae), IJPSR. 2(3): 656- 658.

Uddin, G.M., 1998. Standardization of herbal preparation, The Independent, Monday, 30 March, 13p.

Upadhyay, A.K., A. Kumar,H.S. Mishra, 2010.
Tinospora cordifolia (Willd.)Hook.F. and Thoms.(Guduchi) - Validation of the Ayurvedic pharmacology through experimental and clinical studies. Inter. J. Ayurveda Res., 1(2): 112-121.

Verma, D.R.,A. Kakkar, 2010. Antibacterial activity of Tinospora cordifolia. J. ofGlobal Pharma Technol. 3(11): 08-12.

Vidyadhar, S., M. Saidulu, T.K. Gopal, D. Chamundeeswari, U. Rao,D. Banji, 2010. In vitro antihelmintic activity of the whole plant of Enicostemma littorale byusing various extracts. Inter. J. of Applied Biol. and Pharmaceut.Technolo. 1(3): 1119-1125.

Vuuren, S.F.V., D. Naidoo, 2010. An antimicrobial investigation of plants usedtraditionally in southern Africa to treat sexually transmitted infections. J. Ethnopharmacol.,130: 552558.

Wadood, N., A. Wadood,S.A.W. Shah, 1992. Effect of Tinospora cordifolia on blood glucose and total lipid levels of normal and alloxan-diabetic rabbits. Planta Medica. 58(2) 131.

Wang, G.S., J. Han, L.W. Zhao, D.X. Jiang, Y.T. Liu, X.L. Liu, 2010. Antihelmintic activity of steroidal saponins from Paris polyphylla. Phytomedicine, 17: 1102-1105.

\section{How to cite this article:}

Dwivedi, S.K., and Enespa. 2016. Tinospora cordifolia with Reference to Biological and Microbial Properties. Int.J.Curr.Microbiol.App.Sci. 5(6): 446-465. doi: http://dx.doi.org/10.20546/ijcmas.2016.506.052 